\title{
STATUS OF POTENTIAL NON-TIMBER FOREST PRODUCTS FOR WISE USE AND CONSERVATION IN THE LANGTANG NATIONAL PARK'S BUFFER ZONE
}

BHUVAN KESHAR SHARMA피 AND RAM CHANDRA KANDEL ${ }^{2}$

\author{
${ }^{1}$ Green Governance Nepal \\ Kathmandu, Nepal \\ ${ }^{2}$ Bardiya National Park \\ Thakurdwara, Bardia, Nepal \\ bhuvan_keshars@hotmail.com
}

\section{ABSTRACT}

Non-timber forest products are non-wooded biological resources derived from both natural and managed forests and other wooded areas. The objective of the study was to perform resource assessment for baseline information on the status and distribution of locally prioritized plant based non-timber forest products in Nuwakot and Sindhupalchok districts of Langtang National Park's buffer zones. Consultative workshops and forest inventory techniques were applied to collect data. From the consultative workshops 133 species of plants having use value were identified. It was identified that Gaultheria fragrantissima and Edgeworthia gardneri were more potential species for commercial production and utilization. For commercial production and collection of Gaultheria fragrantissima, buffer zone areas of Nuwakot district will be the better place. Similarly, the commercial production and collection of Edgeworthia gardneri will be better in buffer zone areas of Sindhupalchok district.

Keywords: Langtang National Park, buffer zone, Prominence value, perception

\section{INTRODUCTION}

Non-timber forest products (NTFPs) are a collection of biological resources derived from both natural and managed forests and other wooded areas (Peters,1996). NTFPs are culturally important, cheap and accessible biological resources to local people. On the basis of their use, plant based NTFPs can be categorized in different types (Kochhar, 1992; FAO, 2004; Sharma, 2014). In Nepal, the occurrences of NTFPs have been reported from the all altitudinal range and protected areas. There are 3,172 species of plants and animals which are reported as NTFPs in Nepal. Those included 2,349 species of vascular plants, 65 species of mammals and 758 species of birds (Sharma, 2014).

Langtang National Park (LNP) was established in 1976 by covering $1,710 \mathrm{~km}^{2}$ area of Nuwakot, Rasuwa and Sindhupalchok districts. In 1998, an area of $420 \mathrm{~km}^{2}$ around the park containing 28 Village Development Committees (VDCs) was declared as its buffer zone (DNPWC, 1999; Myint et al., 2000). There are four distinct vegetation zones in LNP (LNP, 2001): sub-tropical zone (<1,000-2,000 m), temperate zone (2,600-3,000 m), lower sub-alpine zone (3,000-34000 $\mathrm{m})$, and alpine zone $(>4,000 \mathrm{~m})$. Realizing the crucial lack of information about the status of NTFPs, this study was undertaken to better understand about the quantitative status of NTFPs 
in the buffer zone of Langtang National Park. The main objective of the study was to perform resource assessment for finding baseline information on the status and distribution of locally prioritized plant based NTFPs in Nuwakot and Sindhupalchok districts of Langtang National Park's Buffer zones.

\section{MATERIALS AND METHODS}

\section{Study sites}

The study sites were located in the southern part of LNP's buffer zone. They were distributed in the subtropical and temperate vegetation zones of Nuwakot and Sindhupalchok districts. The study sites included thirteen VDCs, eight in Nuwakot district and five in Sindhupalchok district. The studied VDCs of Nuwakot are Urleni, Raluka, Rajang, Gjyangphedi, Sikharbesi, Gaunkharka, Samundratar, and Rautbesi. Similarly, the VDCs of Sindhupalchok district are Helambu, Boruwa, Kiul, Selang, and Syaule. Forest inventory were conducted within the altitudinal range of $1,659 \mathrm{~m}$ to $2,412 \mathrm{~m}$ in the buffer zone forest of Nuwakot district. In Sindhupalchok district forest inventory were made between $1,882 \mathrm{~m}$ to $2,620 \mathrm{~m}$ elevation of buffer zone forest.

\section{NTFPs category}

Plant based NTFPs were categorized in 14 different types on the basis of their use. They were: fiber and fiber yielding; sugar starch and cellulose products; legume or pulses; vegetable oils and fats; fruits and nuts; vegetable; starch and cellulose products; spices, condiments and other flavourings; fumitory and masticatory; beverages; dyeing and tannins; medicine; insecticides and herbicides; and miscellaneous (Kochhar, 1992; FAO, 2004; FRA/DFRS, 2014; Sharma, 2014).

\section{Data collection}

Both the qualitative and quantitative techniques were applied for data collection. The qualitative data were collected from the Focus Group Discussion (FGD). This included the name of plants according to their uses, local distribution and their cultivation as well as collection sites. The quantitative data incorporated the number and coverage of each plant species in quadrat. Two approaches namely social and ecological survey were used to collect those data.

\section{Social survey}

This study basically used participatory rapid approach including stakeholder consultation and interaction with focus group discussion (FGD) for data and information collection. The relevant individuals were contacted and uses and distribution of NTFPs in the LNP's buffer zone area were investigated (Mikkelsen, 1995). Informants for the FGD included members of Buffer Zone Users Committees (BZUCs), members of Buffer Zone Users' Groups (BZUGs), members of Buffer zone Community Forests (BZCF), local political leaders, local healers, teachers, and local people. Locations for carrying out FGD and participants from community and local level authorities were identified from prior discussion with LNP officials. The number of participants in one FGD was not exceeded15 personnel.

Prior to the FGD, a checklist regarding use categories of plant was prepared and used during discussion. Name of plant species in each use type were asked and grouped on the specific 
categories. They were also asked to prioritize the identified NTFPs on the basis of their commercial and local uses. The local distributions of the available NTFPs were also identified from the discussion and were marked on the available topographical maps.

During FGD local people were also requested to provide best locality for cultivation and collection of prioritized NTFPs. The basis to identify suitable locations was current regeneration scenario and collection practices of NTFPs.

\section{Ecological survey}

Immediately after collecting the information from FGD, extensive field visits were made for forest inventory by using quadrat method. The survey was conducted in the specified sites identified from the FGD, by using systematic random sampling techniques along the altitudinal gradient of $100 \mathrm{~m}$ difference. The recognized NTFPs were either shrub or herb. So, quadrats of $1 \mathrm{~m} * 1 \mathrm{~m}$ and $5 \mathrm{~m} * 5 \mathrm{~m}$ were utilized to collect data about herbaceous plant and understory species respectively.

Geographical location, elevation and distance from cultivated land of each surveyed plot were recorded by using Geographical Positioning System (GPS). Coverage of the species was identified from ocular estimation. Removal of thin layer from top soil was considered as light erosion. The nomenclatures of plants were provided from the published literatures (DPR, 2002, 2010, 2011, 2012; Sharma, 2014).

\section{Data recording and analysis}

Both the secondary and primary data and information were the sources for this study. Secondary sources of information were published \& unpublished documents and reports. In addition, information from LNP, BZ and local VDCs were also used as the secondary sources of data. The data and information were recorded in data sheets and note books.

Collected data from primary and secondary sources were processed and analyzed. The descriptive statistics such as simple means, frequencies and percentage were used for the analysis of quantitative data. Microsoft excel software was used for data processing.

Local perceptions (\%) about the suitable places of NTFPs cultivation and collection were analyzed by using following formula (Tamrakar \& Sharma, 2002):

$$
\text { Local perception }=\frac{\text { Number of people selected the location }}{\text { Total number of people participated }} * 100
$$

The calculated mean was utilized to analyze prominence value. Frequency, density, mean percent cover and prominence value of the species were calculated by using following formula (Zobel et al., 1987, Sharma et al., 2012):

$$
\text { Frequency }=\frac{\text { Number of quadrat in which species i occurred }}{\text { Total number of quadrats studied }} * 100
$$

$$
\text { Density }=\frac{\text { Total number of individuals of species } i}{\text { Total number of quadrats studied } * \text { Area of a quadrat }} * 10000
$$




\section{Mean Percent Cover $=\frac{\text { Total cover percentage of species } \mathrm{i}}{\text { Total number of plot studied }}$}

Prominence Value $=$ Mean percent cover of species $i * \sqrt{\text { Frequency of species } i}$

\section{RESULTS}

\section{Priority}

Major NTFPs of the LNP buffer zone in Nuwakot district were classified on the basis of their use categories. Two consultative workshops were organized in Ramati village of Samundratar VDC and Timbu village of Helambu VDC of Nuwakot and Sindhupalchok districts respectively. From the consultative workshops 133 species of plants were identified having use value (annex-1). Local peoples $(n=45)$ provided their perception, to prioritize those species with their specific location, during consultative workshop.

Local people perceived that the most useful NTFPs for the Nuwakot district were Gaultheria fragrantissima, Edgeworthia gardneri, Drepanostachyum falcatum, Girardinia diversifolia, Swertia chirayita and Urtica dioica respectively. Most of the local people provided their interest to extract essential oil from Gaultheria fragrantissima. The buffer zone areas of LNP in Nuwakot district are mostly located below 2200 m elevation which is suitable habitat for Gaultheria fragrantissima (Polunin \& Stainton, 1984). The prioritized NTFPs were distributed in all buffer zone forest of LNP in Nuwakot district. Although the general distribution of Edgeworthia gardneri is ranged between 1500 to 3000 m elevations, it was more abundantly distributed above $2200 \mathrm{~m}$ elevation in south-east portion of LNP. So, in the study area the natural habitat of Edgeworthia gardneri is above 2200 m elevation. It is mostly distributed in Gaunkharka VDC and some areas of Urleni VDC. It was observed that above $2200 \mathrm{~m}$ elevation abandoned agricultural land was perfect habitat for Edgeworthia gardneri.

According to local people commercially most useful NTFPs in LNPBZ of Sindhupalchok district were Edgeworthia gardneri, Gaultheria fragrantissima, Swertia chirayita, Juglans regia, and Rubia manjith. In this area people were mostly interested to extract bark of Edgeworthia gardneri for making paper. The buffer zone area of LNP in Sindhupalchok is distributed above 2200 $\mathrm{m}$ elevation, which is suitable habitat for Edgeworthia gardneri. So, there is the potentiality of commercial farming and natural extraction of this species in LNPBZ of Sindhupalchok district. The prioritized NTFPs were distributed in all buffer zone VDCs of LNP in Sindhupalchok district. The natural habitat of Gaultheria fragrantissima is below $2200 \mathrm{~m}$ elevation. It is mostly found in lower altitudinal ranges of Helambu and Kiul VDCs. Similarly, Edgeworthia gardneri is naturally distributed above 2200 m elevation of Helambu, Kiul and other VDCs of LNPBZ. Most of the private lands are remaining uncultivated in the buffer zone areas and there were possibilities of farming Edgeworthia gardneri in those spaces. 
TABLE 1. Distribution of NTFPs in Langtang National Park's buffer zone VDCs.

\begin{tabular}{|l|c|c|}
\hline Name of potential VDCs & Specific places & District \\
\hline Urleni VDC & All areas & Nuwakot \\
\hline Sikharbesi VDC & Ward no 3, 4, 8 & Nuwakot \\
\hline Gaunkharka UC & Ward no. 5, 7, 8 & Nuwakot \\
\hline Boruwa VDC & -- & Sindhupalchok \\
\hline Helambu VDC & Ward no 1-7 & Sindhupalchok \\
\hline Kiul VDC & -- & Sindhupalchok \\
\hline Selang VDC & -- & Sindhupalchok \\
\hline Syaule VDC & -- & Sindhupalchok \\
\hline
\end{tabular}

People were also asked to provide the name of appropriate sites to cultivate and collect the NTFPs from the buffer zone areas. In Nuwakot district, most of the people (65.2\%) identified Urleni was quite suitable VDC for farming of commercially important NTFPs. Similarly, other suitable VDCs were Ghyangphedi, Sikharbesi, Gaunkharka and Samundratar (including Rautbesi VDC). Similarly, in Sindhupalchok district most of the people (66.7\%) perceived Helambu VDC was quite suitable for cultivation and collection of NTFPs. The other suitable VDCs for the commercial cultivation of NTFPs were Boruwa and Kiul (table 2).

TABLE 2. More suitable places of NTFPs cultivation and collection in LNP's buffer zone forests, outcome of the consultative workshops.

\begin{tabular}{|l|c|l|c|}
\hline \multicolumn{2}{|c|}{ Nuwakot district } & \multicolumn{2}{c|}{ Sindhupalchok district } \\
\hline VDCs & $\begin{array}{c}\text { Local perception } \\
(\%)\end{array}$ & VDCs & $\begin{array}{c}\text { Local perception } \\
(\%)\end{array}$ \\
\hline Urleni (including Raluka \& Rajang) & 65.2 & Helambu & 66.7 \\
\hline Gjyangphedi & 60.9 & Boruwa & 50.0 \\
\hline Sikharbesi & 43.5 & Kiul & 22.2 \\
\hline Gaunkharka & 26.1 & Selang & NA \\
\hline Samundratar (including Rautbesi) & 4.3 & Syaule & NA \\
\hline
\end{tabular}

\section{Inventory}

The inventories of NTFPs were conducted within the altitudinal range of $1659 \mathrm{~m}$ to $2412 \mathrm{~m}$ in the LNP's buffer zone forest of Nuwakot district. The slopes of the sampling area were ranging from $30^{\circ}$ to $45^{\circ}$ with the average slope $39^{\circ}$. All survey sites were disturbed by the human activities. Average distance of survey sites to cultivated land was $185 \mathrm{~m}$. Most of the survey plots were distributed in north-western aspect (35\%). While $25 \%, 15 \%, 10 \%, 10 \%$ and $5 \%$ plots were distributed in eastern, western, south-western, south-eastern and north-eastern 
aspects respectively. All survey sites received light erosion. The average cover of understory vegetation in the survey site was $87.5 \%$. In total $12.5 \%$ ground was covered from litters. Lichens were distributed in all survey sites. The data were collected from 63 plots in Nuwakot district.

Inventory in Sindhupalchok district were made between $1882 \mathrm{~m}$ to $2620 \mathrm{~m}$ elevation. The average slope of the sampling area was $19^{\circ}$ and ranging from $5^{\circ}$ to $50^{\circ}$. Survey areas were disturbed by the human activities. The average distance from the survey sites to cultivated land was $755 \mathrm{~m}$. Most of the survey plots were distributed in south-eastern aspect (50\%). While $22 \%, 14 \%$ and $14 \%$ plots were distributed in north-west, south-west and eastern aspect respectively. The survey site received light erosion. Average cover of the understory vegetation in the survey area was $77.5 \%$. In the survey site $45 \%$ ground were covered by the litters. In total $86 \%$ area included mosses while remaining $14 \%$ area included lichens. All together 90 plots were used for data collection in Sindhupalchok district.

In the LNP's buffer zone forests at Nuwakot district, Gaultheria fragrantissima was most prominent $(P V=251.40)$ species in understory layer. Similarly, other more prominent species in this layer were Berberis asiatica, Lyonia ovalifolia and Eurya acuminata with prominence value of 47.73, 30.52 and 29.58 respectively (table 3). In Sindhupalchok district Edgeworthia gardneri was the most prominent $(P V=14.85)$ species in understory layer. Other prominent species in understory layer were Gaultheria fragrantissima $(P V=10.10)$, Lyonia ovalifolia (PV $=3.38$ ) and Berberis asiatica ( $P V=2.73$ ) respectively (table 3 ).

TABLE 3. Prominence value of five most abundant shrub species in LNP's buffer zone forests of Nuwakot and Sindhupalchok districts.

\begin{tabular}{|l|l|l|c|c|}
\hline \multirow{2}{*}{ SN } & \multirow{2}{*}{ Local name } & \multirow{2}{*}{ Scientific name } & \multicolumn{2}{|c|}{ PV } \\
\cline { 4 - 5 } & & & Nuwakot & Sindhupalchok \\
\hline 1 & Patpate & Gaultheria fragrantissima & 251.4 & 10.1 \\
\hline 2 & Chutro & Berberis asiatica & 47.73 & 2.73 \\
\hline 3 & Angeri & Lyonia ovalifolia & 30.52 & 3.38 \\
\hline 4 & Jhigane & Eurya acuminate & 29.58 & -- \\
\hline 5 & Setikath & Myrsine capitellata & 28.76 & -- \\
\hline 6 & Argeli & Edgeworthia gardneri & -- & 14.85 \\
\hline 7 & Banmara & Eupatorium adenophorum & -- & 2.02 \\
\hline
\end{tabular}

Among the herbaceous species Eupatorium adenophorum was the most prominent $(\mathrm{PV}=$ 3.80) species in the LNP's buffer zone forests of Nuwakot district. Simlarly, Polystichium squarrosum (PV $=0.81)$, Imperata cylindrica $(P V=0.42)$ and Aster sp $(P V=0.41)$ were other more prominent herbaceous species in this area (table. 4). In Sindhupalchok district Elsholtzia sp was the most prominent $(P V=3.78)$ herbaceous species in the LNP's buffer zone forest. Similarly, Aster sp (PV = 3.44), Potentilla sp (PV = 2.15) and Cyperus sp (PV = 1.34) were more prominent herbaceous species in this area (table 4 ). 
TABLE 4. Prominence value of five most abundant herbaceous species in LNP's buffer zone forests of Nuwakot and Sindhupalchok district of LNPBZ.

\begin{tabular}{|l|l|l|c|c|}
\hline \multirow{2}{*}{ SN } & \multirow{2}{*}{ Local name } & \multirow{2}{*}{ Scientific name } & \multicolumn{2}{|c|}{ PV } \\
\cline { 4 - 5 } & & & Nuwakot & Sindhupalchok \\
\hline 1 & Banmara & Eupatorium adenophorum & 3.8 & -- \\
\hline 2 & Unau & Polystichum squarrosum & 0.81 & -- \\
\hline 3 & Siru & Imperata cylindrica & 0.42 & -- \\
\hline 4 & Buki & Aster sp & 0.41 & 3.44 \\
\hline 5 & Rubia & Rubia sp & 0.24 & -- \\
\hline 6 & Bansilam & Elsholtzia sp & -- & 3.78 \\
\hline 7 & Bajradanti & Potentilla $s p$ & -- & 2.15 \\
\hline 8 & Mothe & Cyperus $s p$ & -- & 1.34 \\
\hline 9 & Majito & Rubia manjith & -- & 1.29 \\
\hline
\end{tabular}

Natural habitat of Gaultheria fragrantissima is at lower elevation than that of Edgeworthia gardneri. Buffer zone VDCs of Nuwakot district is mostly located at the lower elevation. So, there are higher density of Gaultheria fragrantissima (3140 individuals/ha) than that of Edgeworthia gardneri (360 individuals/ha). Similarly, as the buffer zone VDCs in Sindhupalchok district are located at higher elevation, population of Gaultheria fragrantissima (1314 individuals/ha) is lower than that of Edgeworthia gardneri (3000 individuals/ha) (table 5).

TABLE 5. Density per hector of five most abundant species of understory vegetation in LNP's buffer zone forests of Nuwakot and Sindhupalchok districts.

\begin{tabular}{|c|l|l|c|c|}
\hline \multirow{2}{*}{ SN } & \multirow{2}{*}{ Local name } & \multirow{2}{*}{ Scientific name } & \multicolumn{2}{|c|}{ Density/ha } \\
\cline { 3 - 5 } & & & Nuwakot & Sindhupalchok \\
\hline 1 & Patpate & Gaultheria fragrantissima & 3140 & 1314 \\
\hline 2 & Banmara & Eupatorium adenephorum & 700 & 1086 \\
\hline 3 & Argeli & Edgeworthia gardneri & 360 & 3000 \\
\hline 4 & Khareto & Phyllanthus parvifolius & 360 & -- \\
\hline 5 & Angeri & Lyonia ovalifolia & 320 & -- \\
\hline 6 & Lokta & Daphne bholua & -- & 1000 \\
\hline 7 & Gurans & Rhododendron arboreum & -- & 771 \\
\hline
\end{tabular}




\section{DISCUSSION}

The commercially important NTFPs were using by the local people for some other traditional purposes. In almost all study area, commercially important Gaultheria fragrantissima was utilized for livestock bedding. Langtang National Park established a distillation unit to extract essential oils from Gaultheria in Rasuwa district. After its establishment, Gaunkharka VDC of Nuwakot district banned to collect Gaultheria fragrantissima from buffer zone community forest areas.

Some local people collect and sell the bark of Edgeworthia gardneri to nearby market. There were some traders, in Chanauta bazaar of Sindhupalchok district, who were collecting those bark from local herders. There was no record of other NTFPs which were commercially traded from this area. The commercial use of these valuable products can also threaten their availability. The collection methods used by the local people can accelerate to reduce the population of NTFPs.

Plants are sensitive to the local climatic condition. Small changes in the microclimate may differs their distribution pattern. The current distribution of Gaultheria fragrantissima is between 1200 to 2400 m elevation (Polunin \& Stainton, 1984) in moist and open areas. Similarly, current distribution of Edgeworthia gardneri is between 1500 to 3000 m elevations (Polunin \& Stainton, 1984) in open areas.

All tradable NTFPs play a vital role in the livelihood of local people, although small quantitity of them are commercially used by few people. Among them sporangia of Lycopodium clavatum, fruits of Myrica esculenta, bark of Daphne bholua \& Edgeworthia gardneri, and extracted fibre from Girardiana diversifolia were previously sold by the local people. According to them all these materials were locally sold except the sporangia of Lycopodium clavatum, which was used to collect by external mediator.

The preferred and prioritized species by the local people were naturally available in the buffer zone forests of LNP. As there are enough barren private lands in the buffer zone areas, there are also potentialities of their commercial farming. Some people started to plant and preserved them in their private land.

There are markets for the essential oils of Gaultheria fragrantissima as it is an important constituent for pain relief massages. The fiber of Edgeworthia gardneri is used to make Nepali papers. The Nepali paper is used for all government official processes in Nepal. Similarly, it is used to make different souvenirs and calendars. The semi processed bark of Edgeworthia gardneri is also used for Japanese products (Biggs \& Messerschmidt, 2005).

Buffer zone forest areas of Langtang National Park at Nuwakot and Sindhupalchok districts were quite favourable for NTFPs production. The local people showed their interest for conservation and sustainable use of commercial species. Current study indicated that Gaultheria fragrantissima and Edgeworthia gardneri were more potential species for commercial production and utilization in the study area. For commercial production and collection of Gaultheria fragrantissima, buffer zone areas of Nuwakot district will be the better place. Similarly, the commercial production and collection of Edgeworthia gardneri will be better in Sindhupalchok district as this area incorporated natural habitat of this species. 


\section{ACKNOWLEDGEMENTS}

Department of National Parks and Wildlife Conservation for providing research permission. Langtang National Park is acknowledged for funding arrangement and providing research permit. Buffer zone Management Committee for facilitating the research work. Local peoples are acknowledged for providing their valuable time and necessary information.

\section{ABBREVIATIONS USED}

BZ - Buffer zone, BZCF - Buffer zone community forest, BZUG - Buffer zone users' group, DNPWC - Department of National Parks and Wildlife Conservation, FGD - Focus Group Discussion, LNP - Langtang National Park, LNPBZ - Langtang National Park's Buffer zone, NTFPs - Non-timber Forest Products, PV - Prominence value, VDC - Village Development Committee.

\section{REFERENCES}

BIGGS, S; MESSERSCHMIDT, D (2005) Social responsibility in the growing handmade paper industry of Nepal. Elsevier. DOI: 10.1016/j.worlddev.2005.06.002

DNPWC (1999) Langtang National Park management strategy framework. Department of National Parks and Wildlife Conservation (DNPWC).

DPR (2002) Pteridophytes of Nepal. Department of Plant Resources (DPR), Kathmandu, Nepal; 175 pp. DPR (2010) Catalogue of Nepalese flowering plants - I (Gymnosperms and Monocotyledons). Department of Plant Resources (DPR), Kathmandu, Nepal; 174 pp.

DPR (2011) Catalogue of Nepalese flowering plants - II, Dicotyledons (Ranunculaceae to Dipsacaceae). Department of Plant Resources (DPR), Kathmandu, Nepal; 210 pp.

DPR (2012) Catalogue of Nepalese flowering plants - III, Dicotyledons (Compositae to Salicaceae). Department of Plant Resources (DPR), Kathmandu, Nepal; 255 pp.

FAO (2004) National forest Inventory field manual template. Food and Agriculture Organization of the United Nations, Working Paper 94/E, Rome; 83 pp.

FRA/DFRS (2014) Terai forests of Nepal (2010 - 2012). Forest resource assessment Nepal project/ Department of Forest Research and Survey, Kathmandu, Nepal; 91 pp.

KOCHHAR, S L (1992) Economic botany in the tropics. Macmillan India Limited, Madras, India; $476 \mathrm{pp}$. LNP (2001) Langtang National Park Buffer Zone Management Plan. Langtang National Park (LNP), Nepal. MIKKELSEN, B (1995) Methods for development work and research. Sage Publications, New Delhi, India. MYINT, M; SHRESTHA, I; JOSHI, G (2000) An Inventory on biodiversity study of Langtang National Park \& surrounding area using Geographic Information System \& Remote Sensing. Submitted to MENRIS, ICIMOD, Kathmandu.

PETERS, C M (1996)The ecology and management of non-timber forest resources. World Bank, Washington DC, USA; $157 \mathrm{pp}$.

POLUNIN, O; STAINTON, A (1984) Flowers of the Himalaya. Oxford University Press, Delhi.

SHARMA, B K; CHALISE, M K; SOLANKI, G S (2012) Vegetation types and wildlife occurrence in Baghmara Buffer zone Community Forest, Nepal. International Multidisciplinary Research Journal 2(2): 52-65. 
SHARMA, B K (2014) Bioresources of Nepal. Subidhya Sharma, Nepal; pp 819.

TAMRAKAR, A; SHARMA, B K (2002) Conservation and development of local forest resources and wildlife through community forestry: a case study from Baghmara Community Forest, Chitwan. Banko Jankari 12(1): 49-53.

WOLLENBERG, E; INGLES, A 1998) (eds) Incomes from the forest. Methods for the development and conservation of forest products for local communities. CIFOR/ IUCN, Bogor, Indonesia.

ZOBEL, D B; BEHAN, M J; JHA, P K; YADAV, U K R (1987) A practical manual for ecology. Ratna Book Distributors, Kathmandu, Nepal. 
Annex 1. Outcomes of the stakeholder consultation to identify and prioritize NTFPs in Lantang National Park's buffer zone area.

\begin{tabular}{|c|c|}
\hline Local name and use categories & Scientific name \\
\hline \multicolumn{2}{|l|}{ Fiber and fiber yielding } \\
\hline Kettuke & Agave americana \\
\hline Lokta & Daphne bholua \\
\hline Allo & Girardiana diversifolia \\
\hline Argeli & Edgeworthia gardneri \\
\hline Babiyo & Eulaliopsis binata \\
\hline \multicolumn{2}{|c|}{ Sugar starch and cellulose products } \\
\hline Bantarul & Dioscorea sp \\
\hline Gittha & Dioscorea bulbifera \\
\hline Bhyakur & Dioscorea deltoidea \\
\hline \multicolumn{2}{|l|}{ Legume or pulses } \\
\hline Tanki & Bauhinia purpurea \\
\hline Bhorla & Bauhinia vahlii \\
\hline \multicolumn{2}{|l|}{ Vegetable oils and fats } \\
\hline Okhar & Juglan regia \\
\hline Chiuri & Aesandra butyracea \\
\hline Bolung (Bansilam) & Elsholtzia sp \\
\hline Silam & Perilla frutescens \\
\hline \multicolumn{2}{|l|}{ Fruits and nuts } \\
\hline Kaphal & Myrica esculanta \\
\hline Chutro & Berberis asiatica \\
\hline Bhakiamilo & Rhus javanica \\
\hline Malayo & Viburnum mullaha \\
\hline Ainselu & Rubus ellipticus \\
\hline Aanp & Mangifera indica \\
\hline
\end{tabular}




\begin{tabular}{|c|c|}
\hline Aalubakhara & Prunus domestica \\
\hline Aaru & Prunus persica \\
\hline Lauth salla & Taxus wallichiana \\
\hline Lapsi & Choerospondias axillaris \\
\hline Amala & Phyllanthus emblica \\
\hline Khurpani & Prunus cornuta \\
\hline Bankera & Musa $s p$ \\
\hline Singato & Schisandra grandiflora \\
\hline Guphla & Holboellia latifolia \\
\hline Golkankri & Coccinia grandis \\
\hline Kalo ainselu & Rubus foliolosus \\
\hline Rato Ainselu & Rubus sp \\
\hline Bhuin ainselu & Fragaria nubicola \\
\hline Patpate & Gaultheria fragrantissima \\
\hline Jamanemandro & Mahonia napaulensis \\
\hline Muslindi & Elaeagnus parvifolius \\
\hline \multicolumn{2}{|l|}{ Vegetable } \\
\hline Nyuro & Dryopteris sp \\
\hline Sisnu & Urtica dioica \\
\hline Padamchal & Rheum emodi \\
\hline Thotne & Aconogonum molle \\
\hline Chyau & Mushroom \\
\hline Halhale & Rumex crispus \\
\hline Koiralo & Bauhinia variegata \\
\hline Siplikan (Chiniya) & Crateva unilocularis \\
\hline Tusa & Dendracalamus falcata \\
\hline Dundu & Allium tuberosum \\
\hline Banlasun & Allium sp \\
\hline
\end{tabular}




\begin{tabular}{|c|c|}
\hline Kalonyuro & Dryopteris concolor \\
\hline Jirenyuro & Actiniopteris sp \\
\hline Kurilo & Asparagus racemosus \\
\hline Tama & Dendracalamus $s p$ \\
\hline \multicolumn{2}{|c|}{ Spices, condiments and other flavorings } \\
\hline Tejpat & Cinnamomum tamala \\
\hline Timbur & Zanthoxylum armatum \\
\hline Jimbu & Allium hyposistum \\
\hline Silam & Perilla frutescens \\
\hline Siltimbur & Lindera neesiana \\
\hline Jangali timbur & Zanthoxylum acanthopodium \\
\hline \multicolumn{2}{|c|}{ Fumitory and masticatory } \\
\hline Dhairo & Woodfordia fruticosa \\
\hline Khasru & Quercus semicarpifolia \\
\hline Kuro & Bidens pilosa \\
\hline Pashanbet & Bergenia ciliata \\
\hline Saur (Chipsing) & Betula alnoides \\
\hline Thulo okhati & Astible rivularis \\
\hline Kanchopat & Nicotiana tabacum \\
\hline \multicolumn{2}{|l|}{ Beverages } \\
\hline Gurans & Rhododendron arboreum \\
\hline Malayo & Viburnum mullaha \\
\hline Chutro & Barberis asiatica \\
\hline Ainselu & Rubus ellipticus \\
\hline Jamanemandro (Kerpa) & Mahonia napaulensis \\
\hline Kaphal & Myrica esculenta \\
\hline \multicolumn{2}{|l|}{ Dyeing and tannins } \\
\hline Titepati & Artemisia vulgaris \\
\hline
\end{tabular}




\begin{tabular}{|l|l|}
\hline Chutro & Berberis asiatica \\
\hline Musurekatush & Castanopsis tribuloides \\
\hline Jamanemandro (Kerpa) & Mahonia napaulensis \\
\hline Majito & Rubia manjith \\
\hline Kaphal & Myrica esculenta \\
\hline Aanp (leaf) & Mangifera indica \\
\hline Phalant & Quarcus glauca \\
\hline Okhar & Juglan regia \\
\hline Medicine & \\
\hline Akashbeli & Cuscuta reflexa \\
\hline Akashbeli & Lycopodium clavatum \\
\hline Amala & Phyllanthus emblica \\
\hline Bankapas & Thespesia lampas \\
\hline Bantulsi & Rabdosia sp \\
\hline Barro & Terminalia bellirica \\
\hline Batulpate & Stephania elegans \\
\hline Chirayto & Swertia chirayita \\
\hline Chutro & Berberis asiatica \\
\hline Dhasingare (Patpate) & Gaultheria fragrantissima \\
\hline Ghiyaukumari & Aloe vera \\
\hline Ghodtapre & Centella asiatica \\
\hline Golkankri & Coccinia grandis \\
\hline Gurjo & Tinospora cordifolia \\
\hline Halhale & Rumex crispus \\
\hline Harro & Terminalia chebula \\
\hline Indreni & Trichum fimbriatum \\
\hline Jibanti & \\
\hline Jugargano & Dellichiana \\
\hline
\end{tabular}




\begin{tabular}{|l|l|}
\hline Kurilo & Asparagus racemosus \\
\hline Kutki & Neopicrorhiza scrophulariflora \\
\hline Lajjabati & Mimosa pudica \\
\hline Lankuri & Fraxinus floribunda \\
\hline Malati & Mirabilis jalapa \\
\hline Neem & Azadirachta indica \\
\hline Padamchal & Rheum emodi \\
\hline Panchaunle & Dactylorhiza hatagirea \\
\hline Parijat & Nyctanthes arbor-tritis \\
\hline Pashanbhed & Bergenia ciliata \\
\hline Pyauli & Reinwardtia indica \\
\hline Sisnu & Urtica dioica \\
\hline Taxus & Taxus wallichiana \\
\hline Thulo aushadhi & Astible rivularis \\
\hline Timur & Zanthoxylum armatum \\
\hline Tite Nigalo & Arundinaria sp \\
\hline Titepati & Artemisia indica \\
\hline Insecticides and herbicides & Prunus domistica \\
\hline Aarubakhara & Melia azederach \\
\hline Bakaina (leaf) & Sapium insigne \\
\hline Khirro (leaf) & Engelhardia spicata \\
\hline Mauwa & Azadirachta indica \\
\hline Neem & Zanthoxylum armatum calamus \\
\hline Timur & Artemisia vulgaris \\
\hline Titepati & \\
\hline Bojho & Acorus \\
\hline
\end{tabular}




\begin{tabular}{|c|c|c|}
\hline \multicolumn{3}{|l|}{ Miscellaneous } \\
\hline Local name & Scientific name & Local use \\
\hline Banmara & Eupatorium adenophorum & Fodder \\
\hline Dhupi & Juniperus sp & Religious \\
\hline Gurans & Rhododendron arboreum & Ornamental, Religious \\
\hline Khanayo & Ficus semicordata & Fodder \\
\hline Khasru & Quercus semicarpifolia & Fodder \\
\hline Maharangi & Maharanga emodi & Religious, Medicinal \\
\hline Musurekatush & Castanopsis tribuloides & Fodder \\
\hline Nagbeli & Lycopodium clavatum & Gun powder, Ornamental \\
\hline Nigalo & Dendrophthoe falcata & Fodder \\
\hline Rittha & Sapindus mukorossi & Soap \\
\hline Sungava & Orchids & Ornamental \\
\hline Sunpate & Rhoodendron anthopogon & Religious \\
\hline Tatelo & Oroxylum indicum & Religious \\
\hline Titepati & Artemisia indica & Religious \\
\hline
\end{tabular}

